\title{
Editorial II
}

\section{Homenagem ao Membro do Conselho Editorial}

\author{
Yotaka Fukuda \\ (1945-2010)
}

Eu me encontrava em um navio, durante o Congresso da Fundação Otorrinolaringologia, realizado em fins de 2008, quando soube que o Yotaka, que eu esperava encontrar a bordo, se encontrava na Unidade de Terapia Intensiva do Hospital São Paulo, em virtude de uma pneumonia grave. A pneumonia sarou, mas sua antiga fibrose pulmonar se agravou e ele se tornou dependente de oxigênio. Durante estes anos que se passaram esteve internado diversas vezes, com diversas infecções. A última vez que conversamos foi no casamento de seu filho, no qual ele fez um discurso emocionado e lindo. Algum tempo depois deixou a festa, pois não se sentia bem. Na manhã seguinte foi levado ao Hospital Albert Einstein, onde foi imediatamente conduzido à UTI. Ainda o visitei algumas vezes, até o seu falecimento no dia 18 de julho.

Yotaka fez toda a sua carreira universitária na Escola Paulista de Medicina. Entrou na Escola em 1966, foi meu residente de 1972 a 1974, terminou seu Mestrado em 1981 e o Doutorado em 1982. Em 1993 prestou o seu concurso de Docência Livre.

Não sei dizer quando ele deixou de ser um dos meus assistentes para tornarse meu parceiro e meu amigo. Sei que trabalhamos juntos no primeiro implante coclear, realizado em 1977, assim como em todos os outros, até o início de sua doença. Praticamos inúmeras intervenções cirúrgicas juntos, havia entre nós aquela perfeita sinergia em que qualquer um podia fazer qualquer parte do procedimento. Mas os seus dedos eram mágicos na dissecção dos tumores do ângulo ponto-cerebelar.

Dedicou-se muito, também, aos potenciais elétricos auditivos. Aprendemos com Jean Marie Aran a eletrococleografia e aos poucos fomos expandindo nosso campo de ação para outros potenciais auditivos e para a estimulação elétrica do promontório. Mas foi ele quem comandou, durante muitos anos, no nosso serviço, a clínica e a pesquisa desses potenciais. Sua tese de Mestrado foi um estudo da audiometria de tronco cerebral nos schwannomas vestibulares.

Mas o seu talento era múltiplo. Sua tese de doutorado foi uma pesquisa sobre as afecções da orelha interna por alterações do metabolismo dos glicídios, pesquisa esta que deu origem a toda uma linha de trabalhos científicos. Levei um exemplar de sua tese ao Antonio De la Cruz, um outro grande amigo que também nos deixou precocemente. Escreveu-me dizendo que considerava a tese do Yotaka o mais completo estudo sobre o metabolismo dos carboidratos 
até então realizado. Ao longo dos anos, e de muitos outros trabalhos, ela deu origem ao seu livro Açúcar: Amigo ou Vilão? publicado em 2003.

Na sua docência livre voltou à audiologia eletroencefálica, estudando o $\mathrm{P}_{300^{\circ}}$

Fez numerosos estudos experimentais, estimulando intensamente os mestrandos e doutorandos que receberam sua orientação nas suas teses. Foi incansável ao ensinar residentes e desenvolver suas aptidões para a otorrinolaringologia.

Estagiou com Antonio De la Cruz e Derald Brackmann, no Instituto House, em Los Angeles, para aperfeiçoar as suas técnicas cirúrgicas translabiríntica e subtemporal, e com Naoaki Yanagihara, na Universidade de Ehime, onde participou de pesquisas sobre o nervo facial e tomou contato com os primeiros aparelhos de surdez implantáveis (e aproveitou, também, para aperfeiçoar o seu japonês).

Mas, acima de tudo, tivemos uma grande amizade, que me trouxe uma percepção toda especial da cultura japonesa, que ele me ensinou a apreciar. Foi realmente um amigo muito especial, de quem sentirei muita falta e muita saudade. Ele foi, ao mesmo tempo, meu discípulo e meu mestre.

\section{Pedro Luiz Mangabeira Albernaz}

Professor Titular de Otorrinolaringologia - UNIFESP / EPM 